\title{
Analysis of the interaction scheme of agronomic traits of spring triticale
}

\author{
Irina G. Grebennikova ${ }^{1, *}$, and Alexander P. Grebennikov ${ }^{2}$ \\ ${ }^{1}$ Siberian Federal Scientific Center of Agro-BioTechnologies of the Russian Academy of Sciences, \\ Krasnoobsk, Novosibirsk region, Russia \\ ${ }^{2}$ Novosibirsk State University, Novosibirsk, Russia
}

\begin{abstract}
The article presents the results of the correlation and cluster analysis of the relationship of grain productivity with morphobiological and agronomic traits in the breeding of forage spring hexaploid triticale varieties. Evaluation of the matrix of paired phenotypic correlations made it possible to determine the elements of the yield structure necessary to increase the efficiency of selection for individual traits and increase plant productivity. The results of many years of research made it possible to identify agronomic valuable samples of spring triticale. These samples are of interest as a starting material for practical breeding in the West Siberian region.
\end{abstract}

\section{Introduction}

Spring triticale is a crop with high yield potential and a high content of protein and essential amino acids. This determines its food and feed value. [1]. Triticale successfully combines high ecological plasticity of rye and wheat yield $[2,3]$. However, the spread of triticale in the region is constrained by significant yield fluctuations and the lack of adapted varieties to meet the diverse production requirements. The study of qualitatively new genetic sources and the revealing of especially valuable traits or their complexes against a natural background will significantly increase the efficiency of creating a promising breeding material adapted to environmental conditions. The most important condition for the effective use of the potential of the studied samples is the knowledge of the relationships between grain productivity, morphobiological and agronomic valuable traits of plants [4]. The research of correlations in the selection of a grain-fodder variety of spring triticale in the conditions of the West Siberian forest-steppe of the $\mathrm{Ob}$ region will make it possible to determine through which elements of the yield structure it is possible to more effectively increase the productivity of plants, predict an increase in the selection efficiency for individual characteristics and optimize the breeding process.

The aim of this work was to determine the relationship between the spring triticale yields in various weather conditions with the elements of the crop structure and to identify the sources of valuable traits of breeding samples of spring triticale.

\footnotetext{
* Corresponding author: sibfti.grig@ngs.ru
} 


\section{Materials and Methods}

The material was the test data of three varieties of spring wheat (Novosibirskaya 15, Novosibirskaya 31, Sibirskaya 12) and four forms of spring triticale (K-3992, Ukro, F10 Sears57 × Ukro, Kissa p / o) obtained during field experiments in 2018-2020 (Table 1). The breeding form F10 Sears $57 \times$ Ukro is an original hybrid material obtained in 2009 by the method of diallelic crosses of the winter variety Sears 57 and the spring triticale Ukro [5]. Breeding samples are characterized by different ecological and geographical origin and belong to different groups of ripeness. The standard of spring triticale is absent in the region and comparison was made with wheat varieties of Siberian breeding. Field experiments were carried out on land plots geographically located in the Priobskaya forest-steppe of the Novosibirsk region. Sowing was carried out manually in open ground in four replications, 80 grains in a row with a feeding area of $0,3 \mathrm{~m}^{2}$.

Table1. Studied triticale lines and wheat varieties.

\begin{tabular}{|c|c|c|c|c|c|}
\hline No & Crop & Variety & \begin{tabular}{|c|} 
Ripeness \\
group
\end{tabular} & Origination & Agronomic traits \\
\hline 1 & \multirow{3}{*}{$\begin{array}{l}\text { Common } \\
\text { wheat }\end{array}$} & Novosibirskaya 15 & Early & $\begin{array}{c}\text { Russia, } \\
\text { Novosibirsk, } \\
\text { SRIPCB }\end{array}$ & $\begin{array}{l}\text { Resistant to lodging, moderately drought-resistant. } \\
\text { Moderately susceptible to common bunt. Strongly } \\
\text { susceptible to brown and stem rusts, powdery } \\
\text { mildew. }\end{array}$ \\
\hline 2 & & Novosibirskaya 31 & $\begin{array}{l}\text { Mid- } \\
\text { early }\end{array}$ & $\begin{array}{c}\text { Russia, } \\
\text { Novosibirsk, } \\
\text { SRIPCB }\end{array}$ & $\begin{array}{l}\text { Resistant to lodging, moderately drought-resistant. } \\
\text { Moderately susceptible to brown rust and septoria. } \\
\text { Strongly susceptible to loose smut }\end{array}$ \\
\hline 3 & & Sibirskaya 12 & Mid-late & $\begin{array}{c}\text { Novosibirsk, } \\
\text { SRIPCB }\end{array}$ & $\begin{array}{l}\text { Resistant to lodging, drought tolerant. Moderately } \\
\text { susceptible to septoria. Strongly susceptible to } \\
\text { loose smut, brown rust and powdery mildew. }\end{array}$ \\
\hline 4 & \multirow{4}{*}{$\begin{array}{l}\text { Spring } \\
\text { triticale }\end{array}$} & K-3992 & Early & $\begin{array}{c}\text { Russia, } \\
\text { St. } \\
\text { Petersburg, } \\
\text { VIR } \\
\end{array}$ & $\begin{array}{l}\text { Medium-dense ear, with long awns. Resistant to } \\
\text { lodging. Susceptible to ergot fungi. }\end{array}$ \\
\hline 5 & & $\begin{array}{l}\text { Kissa }(\mathrm{k}-3721) \\
\text { (with medium } \\
\text { awn length) }\end{array}$ & Middle & Mexico & $\begin{array}{l}\text { Plants with medium awn length were selected. } \\
\text { Dense ear. High quality grains. Resistant to } \\
\text { lodging. Drought tolerant. Powdery mildew } \\
\text { resistant. }\end{array}$ \\
\hline 6 & & Ukro (k-3644) & Middle & $\begin{array}{l}\text { Russia, } \\
\text { Ukrain }\end{array}$ & $\begin{array}{l}\text { Dense ear with long awns. High quality grains. } \\
\text { Resistant to lodging. Drought tolerant. Powdery } \\
\text { mildew resistant }\end{array}$ \\
\hline 7 & & Sears $57 \times$ Ukro & Late & $\begin{array}{c}\text { Russia, } \\
\text { Novosibirsk, } \\
\text { ICG }\end{array}$ & $\begin{array}{l}\text { Obtained from diallel crosses. Low stem, } \\
\text { Resistant to lodging. Dense ear, awnless. Powdery } \\
\text { mildew resistant. }\end{array}$ \\
\hline
\end{tabular}

To assess the environmental adaptability of varieties, the following agrotechnical methods were used: 1) field trials in different soil conditions; 2) field trials in three different length of daylight. Plants were grown on a natural background. Due to the variety of meteorological conditions during the years of the experiments, contrasting growing conditions were provided, which made it possible to thoroughly analyze the studied samples. So, in May 2018, there was a significant heat deficit. The amount of precipitation significantly exceeded the average longterm values in the first half of the growing season. In 2019 and 2020 a typical early summer drought of moderate intensity was observed. Temperature deviations in 2019 were within the normal range throughout the growing season. Altogether 2020 was the most favorable for plant growth and development. 
Mathematical processing of data and analysis of the relationship of features was carried out using computer programs "Indicators of stability of varieties of agricultural crops" and "Integral breeding assessment of crops".

\section{Results and Discussion}

To differentiate the test samples, pairwise correlations of 10 traits were calculated: stem length, ear length, number of spikelets per ear, density of an ear, number of grains per ear, grains weight per ear, weight of 1000 grains, number of stems per plot, yield, number of days between germination and heading.

Analysis of the correlation matrices allowed us to conclude that the traits "spike length", "number of grains per ear", "number of spikelets per ear", "grains weight per ear" and "number of days between germination and heading" form a correlation group for both wheat and for triticale. There was a high level of correlations between all pairs of traits in this group $\left(0.46<r_{i j}<0.91\right)$. The medium linear dependence was observed between the traits " weight of 1000 grain" and "ear density" in wheat $(r=0.31)$ and between the traits " weight of 1000 grains" and "stem length" in triticale $(r=0.5)$. The yield showed a high correlation with the trait "number of stems per plot" for both crops $(r=0.68 ; r=0.71)$ (table 2).

Table 2. Correlation matrix of traits of four spring triticale varieties at three sowing dates, 2018-2020.

\begin{tabular}{|c|c|c|c|c|c|c|c|c|c|c|}
\hline & \begin{tabular}{|c|} 
Stem \\
Length
\end{tabular} & $\begin{array}{c}\text { EarLen } \\
\text { gth }\end{array}$ & $\begin{array}{c}\text { Spikelets } \\
\text { PerEar }\end{array}$ & $\begin{array}{c}\text { Ear } \\
\text { Density }\end{array}$ & $\begin{array}{l}\text { Grains } \\
\text { PerEar }\end{array}$ & $\begin{array}{l}\text { GWeight } \\
\text { PerEar }\end{array}$ & $\begin{array}{c}\mathrm{W} \\
1000\end{array}$ & $\begin{array}{l}\text { Num } \\
\text { Ears }\end{array}$ & Yield & \begin{tabular}{|c} 
ShEari \\
ng \\
\end{tabular} \\
\hline $\begin{array}{c}\text { Stem } \\
\text { Length }\end{array}$ & 1.00 & 0.09 & -0.12 & $-0.34 *$ & $-0,14$ & 0,12 & $0,50 *$ & $-0,01$ & 0,19 & $-0,28 *$ \\
\hline $\begin{array}{c}\text { Ear } \\
\text { Length }\end{array}$ & & 1.00 & $0.90 *$ & $0.48 *$ & $0,85^{*}$ & $0,79 *$ & 0,11 & $-0,01$ & $0,42 *$ & $0,70 *$ \\
\hline $\begin{array}{l}\text { Spikelets } \\
\text { PerEar }\end{array}$ & & & 1.00 & $0.80 *$ & $0.85^{*}$ & $0.72 *$ & -0.04 & -0.05 & $0.32 *$ & $0.83 *$ \\
\hline $\begin{array}{c}\text { Ear } \\
\text { Density }\end{array}$ & & & & 1.00 & $0.55^{*}$ & $0.39 *$ & -0.19 & -0.06 & 0.11 & $0.75^{*}$ \\
\hline $\begin{array}{l}\text { Grains } \\
\text { PerEar }\end{array}$ & & & & & 1.00 & $0.88^{*}$ & 0.01 & -0.05 & $0.30 *$ & $0.82 *$ \\
\hline $\begin{array}{l}\text { GWeight } \\
\text { PerEar }\end{array}$ & & & & & & 1.00 & $0.47^{*}$ & -0.17 & $0.29 *$ & $0.69 *$ \\
\hline W1000 & & & & & & & 1.00 & $-0.27^{*}$ & 0.06 & -0.04 \\
\hline NumEars & & & & & & & & 1.00 & $0.71 *$ & 0.02 \\
\hline Yield & & & & & & & & & 1.00 & 0.21 \\
\hline ShEaring & & & & & & & & & & 1.00 \\
\hline
\end{tabular}

* Significant at the $\mathrm{p}<0.05$ level

For a visual representation of the correlation groups, a cluster analysis was performed based on the correlation matrix of similarity. As a result, three clusters of traits were identified for wheat and triticale, but the set of traits was different (Fig.1). 


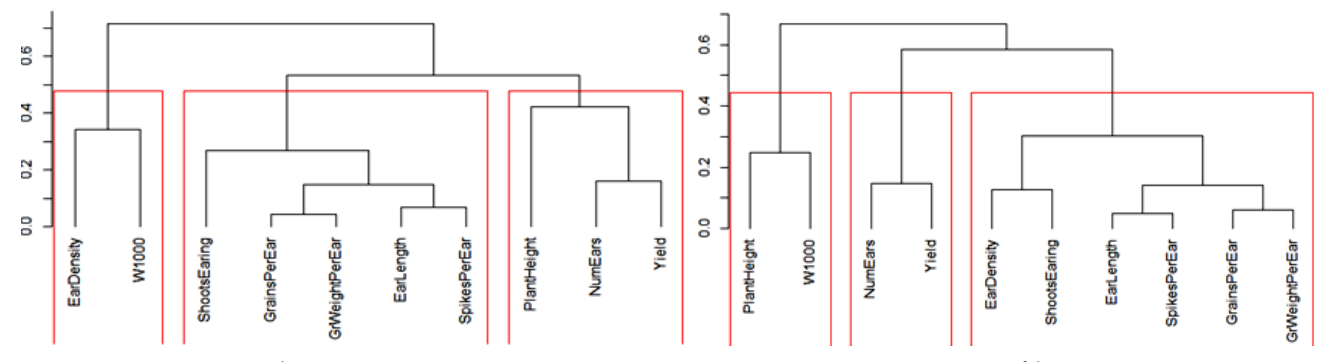

a)

b)

Fig. 1. Dendrograms of quantitative traits: a) wheat, b) triticale.

Growing conditions significantly affected the parameters of yield and elements of its structure. In studying the morphobiological features of the studied samples of spring triticale, we found that the grain forage varieties are characterized by high ear productivity potential, however, in some cases realized not in full. The productivity of the ear is formed both by increasing the number of grains in it and by increasing their weight. Grain size is a feature of triticale. There is information that the grain of this crop is larger and more aligned than that of wheat and rye [7]. Breeding experience data over a three-year study period confirms this statement (fig. 2).
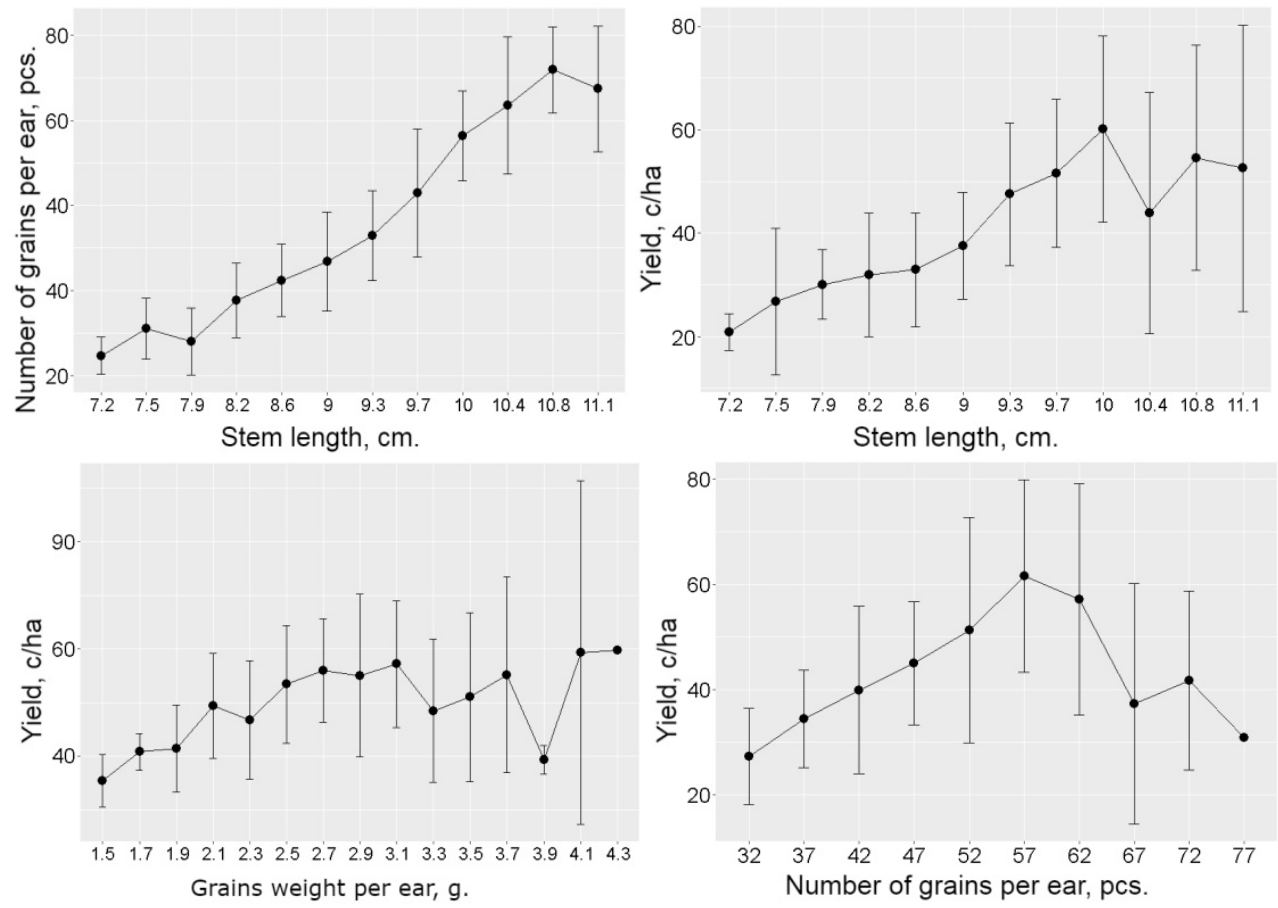

Fig. 2. Relationships between yield and elements of the spring triticale crop structure for 2018-2020.

All plants of the studied samples of triticale consistently had a well-grained ear and formed large grains with a mass with «weight of 1000 grains» about $50 \mathrm{~g}$ and more, which significantly exceeded this trait for wheat. The variety Ukro for the first sowing date was characterized by the maximum value of the trait " weight of 1000 grains " - $65.7 \mathrm{~g}$. Moreover, this value varied slightly from year to year. This sample is of interest for breeding as a source of large grain. 
The value of the parameter "ear length" was in the range from $7 \mathrm{~cm}$ (Novosibirskaya $15)$ to $11 \mathrm{~cm}$ (Novosibirskaya 31). Early-maturing forms of triticale had the lowest value of the trait. This parameter of triticale was characterized by a more uniform value and weakly depended on the sowing time. Samples of triticale with spike lengths from 9.3 to $10 \mathrm{~cm}$ had the highest yield. In this case, the largest number of grains in an ear was formed when its length was from 10 to $11 \mathrm{~cm}$ (fig. 2).

The range of variation of the trait "number of grains in the ear" in the experiment strongly depended on the crop and sowing period. Wheat varieties formed the maximum value of this feature at the second sowing date (from 39,5 pcs for Novosibirskaya 15 to 53 pcs for Novosibirskaya 31). Early ripening varieties Novosibirskaya 15 and K-3992 were characterized by a weak grain size of the ear. Hybrid F10 Sears $57 \times$ Ukro at the third sowing period had the maximum value of this feature - 65 pcs. The triticale samples with the number of grains per spike from 52 to 57 were characterized by the maximum yield. The yield of breeding samples sharply decreased when the number of grains per spike exceeded 64 pieces.

The trait "grain weight per ear" in wheat ranged from $1.2 \mathrm{~g}$ (Novosibirskaya 15) to 1.97 g (Sibirskaya 12). Samples of triticale Ukro, Kissa, and the hybrid F10 Sirs57×Ukro exceeded this index two times or more (3.1 to $3.28 \mathrm{~g})$. The maximum value of ear productivity had the variety Ukro at the second sowing date $-3.3 \mathrm{~g}$. The highest yielding samples formed the weight of grains per ear from 2.9 to $3.1 \mathrm{~g}$.

The interphase period "sprouting - heading" varied depending on the sowing time for the studied samples in the range of 37-48 (first sowing time), 35-46 (second sowing time), and 33-48 days (third sowing time). The range of variability in the period "sprouting - earing" between triticale samples was from 13 to 17 days.

Earing of the earliest ripening sample of triticale K-3992 of the third sowing period occurred on average on the 33rd day and was ahead of the early ripening wheat variety Novosibirskaya 15 in terms of this indicator. Using this collection material containing early maturity genes, it is possible to solve the issues of late maturity of triticale. The triticale varieties Ukro and Kissa corresponded to the late maturing wheat Sibirskaya 12 according to this indicator. The maximum number of days of the interphase period "shoots-earing" was observed for hybrid triticale F10 Sears $57 \times$ Ukro and varied from 46 to 48 days, depending on the time of sowing.

The trait "plant height" is directly related to lodging resistance and, consequently, to the productivity index. The short stem has an advantage over the long stem because it is more resistant to lodging when exposed to heavy rains accompanied by strong winds. In the conditions of Western Siberia, such weather conditions are the main cause of lodging in huge tracts, even in favorable years, when a high crop is formed [8]. However, too short plants (dwarf plants) are relatively fine-grained and are low-productive. The plant height of the studied samples ranged from 81 to $102 \mathrm{~cm}$. The variety Ukro had the maximum value of plant height and showed low lodging resistance at a height of $106 \mathrm{~cm}$ or more. The minimum stem length of the hybrid F10 Sears $57 \times$ Ukro was $82-85 \mathrm{~cm}$. The correlation analysis revealed a weak positive relationship between the yield and plant height in wheat $\left(\mathrm{r}=0.29^{*}\right)$ and triticale $(\mathrm{r}=0.19)$. Analysis of the data suggests that in the breeding process when creating high-yielding varieties, we should consider spring triticale plants with a stem height in the range from 95 to $100 \mathrm{~cm}$, since varieties with this stem length form the maximum yield.

Different rates of plant development of varieties and crops eventually had a significant impact on the integral indicator - grain yield, which is based on numerous correlative relationships between a whole set of interrelated and subordinate traits. The lowest yield of all tested samples was observed at the third sowing date. The following regularity was revealed in the studies: a decrease in the number of plants before harvesting in the studied triticale samples led to a decrease in productivity $\left(\mathrm{r}=0.71^{*}\right)$. So hybrid F10 Sears $57 \times$ Ukro 
was not inferior to the samples Ukro and Kissa by grain weight from the main ear and weight of 1000 grains, but inferior in the number of plants before harvesting, which had a negative impact on its productivity. The highest yield was mainly due to the best ear ear ear and high grain weight per ear of triticale Ukro and Kissa, which maximally realized their productivity potential at the first two sowing dates $-693 \mathrm{~g} / \mathrm{m} 2$ and $441 \mathrm{~g} / \mathrm{m}^{2}$, respectively. The high-yielding forms had the best spikelet grains and high grain weight per spikelet in all weather conditions.

Summarizing the three-year research results, it should be noted that the variability of growing conditions in different years significantly affected the yield of breeding samples. The timing of sowing influenced the increase in yield variability. The difference between the average yields in the experiment by sowing dates within a year was: 2018. - for wheat $363 \mathrm{~g} / \mathrm{m}^{2}$, for triticale $767 \mathrm{~g} / \mathrm{m}^{2} ; 2019-314 \mathrm{~g} / \mathrm{m}^{2}$ and $484 \mathrm{~g} / \mathrm{m}^{2} ; 2020$. -460 and $615 \mathrm{~g} / \mathrm{m}^{2}$, respectively. However, the correlations between the main pairs of traits by year in most cases were characterized by high stability.

\section{Conclusion}

Correlation relationships and cluster analysis showed that the length of the ear, the number of grains in the ear, the number of spikelets in the ear, the weight of grain per ear and the number of stems per plot had the greatest influence on the yield of triticale grain from the elements of yield structure that we studied. To a lesser extent, the yield was related to plant height and weight of 1000 grains. Research data show that at different dates of sowing the critical stages of plant development take place in different light and temperature regimes and air and soil moisture, which changes the metamer (Metamerism) of the plant and the ear, and ultimately affects the productivity of the plant. It was found that under favorable conditions and observance of agrotechnics of cultivation, the studied samples of triticale are able to produce high yields. As a result of many years of research, economically valuable samples of spring triticale that are of interest as a source material for practical breeding in the West Siberian region have been isolated.

\section{References}

1. I. Brzozowska, J. Brzozowski, I. Cymes, J. Elem., 23(4), 1387-1397 (2018) DOI: 10.5601/jelem.2018.23.1.1589

2. F. Zhu, Food Chemistry, 241, 468-479 (2018)

3. Z. Feng, Z. Qi, D. Du et al., The Crop Journal, 7(5), 598-607 (2019)

4. R. Dogan, E. Senyigit, J. Biol. Environ. Sci. 10(28), 21-27 (2016)

5. I.G. Grebennikova, A.F. Aleynikov, Stepochkin Diallel analysis of the number of spikelets per spike in spring triticale. Bulgarian Journal of Agricultural Science. 2011. T. 17. № 6. C. 755-759.

6. I.G. Grebennikova, A.F. Cheshkova, D.I. Chanyshev, P.I. Stepochkin, The use of computer software in applied problems of artificial selection, Spatial Data Processing for Monitoring of Natural and Anthropogenic Processes, 68-73 (CEUR Workshop Proceedings, 2019)

7. V.M. Sokolov, P.I. Stepochkin, Feeding agricultural animals and fodder production 10, 3-6 (2011)

8. R.A. Tsilke, Genetics, cytogenetics and plant breeding, 621 (Novosibirsk: NSAU, 2003) 